\title{
Toward a Problematics of Postcolonialism: The Gay/Minor Science in Bhabha and Deleuze
}

\author{
Che-ming Yang \\ Assoicate Professor \\ Department of Foreign Languages and Literature, National Cheng Kung University, Taiwan \\ E-mail: yang5692@mail.ncku.edu.tw
}

Received: February 3, 2012

Accepted: February 20, 2012

Published: June 1, 2012

doi:10.5539/ells.v2n2p71

URL: http://dx.doi.org/10.5539/ells.v2n2p71

\begin{abstract}
This paper aims to survey from a postcolonial perspective the construction of subject(ivity) in literary narratives through an analogical study of some related theories of Homi Bhabha and Deleuze, regardless of some of their foundational differences in deconstructing the discursive hierarchies. On the one hand, echoing Said, who is considered a foundational text in postcolonial theory, both Bhabha and Deleuze try to deconstruct the common assumptions of cultural/discursive (e.g. race, gender, class) hierarchies, although it is clear that both of them may reject this label (postcolonialism). On the other hand, departing from Said and many other key postcolonial theorists, Bhabha and Deleuze explore the constructive aspects of minor/minoritarian literature that may serve as a counter-discourse (resistance literature) against the majoritarian/colonial discourse.
\end{abstract}

Keywords: Postcolonialism, Subjectivity, Gay/minor science, Bhabha, Deleuze

The State is sovereignty. But sovereignty only reigns over what it is capable of internalizing, of appropriating locally. . . But the war machine's form of exteriority is such that it exists only in its own metamorphoses; it exists in an industrial innovation as well as in a technological invention, in a commercial circuit as well as in a religious creation, in all flows and currents that only secondarily allow themselves to be appropriated by the State. It is in terms not of independence, but of coexistence and competition in a perpetual field of interaction ...

\section{Deleuze and Guattari, A Thousand Plateaus}

\section{Introduction}

In the field of cultural studies, it is always hard to define postcolonialism, just like postmodernism. There have been enormous scholarships of debates on the relationship between postcolonialism and postmodernism. Moreover, these two terms are highly controversial, exasperating, and even contradictory, for both of them reveal great self-reflexivity in their incorporation of creation and critique, the parodying text and the parodied one. Linda Hutcheon's definition of postmodernism also fits postcolonialism in that either of them "uses and abuses, installs and then subverts, the very concepts it challenges" (1). In addition, like postmodernism, postcolonialism is characterized by a prefix "post" that signifies several things at the same time: (1) coming after, (2) negating, (3) continuing, or even (4) appropriating, their predecessors, namely, colonialism and modernism, respectively. Most importantly, echoing postmodernist theorists, postcolonial critics are characterized by their interest in deconstructing the common assumptions of cultural/discursive (e.g. race, gender, class) hierarchies.

Though having some foundational differences in their strategies of decolonization, Bhabha and Deleuze (and Guattari) in many of their works take pains to interrogate and destabilize fixed ideas of identity while celebrating the liminal identity, which is characteristic of the postcolonial condition. Moreover, both of them emphasize the vitalities and potentialities of borderline existence (in-betweenness). Though heavily influenced by psychoanalytical thinking, a target Deleuze and Guattari aim to rewrite and subvert, Bhabha echoes Deleuze and Guattar's rhizomatic view of reality and subjectivity. Most importantly, unlike many Eurocentric postcolonial critics who argue that the colonized Other has been further negated or marginalized by academic theories, both Bhabha and Deleuze have taught critics how to decipher "signs of resistance on the part of the colonized in colonial discourse" (Rossington, 1995, p. 53).

Unlike Edward Said, who writes some foundational texts in postcolonial theory that strongly condemns the West's 
dominant representation of the Orient that leads to an unequal relationship of political, economic, and even imaginative between the Orient and the West, both Bhabha and Deleuze's theories of postcolonialism demonstrate rather the positive aspects of (self-) Orientalaization. On the one hand, echoing Said, both Bhabha and Deleuze show great interest in deconstructing the common assumptions of cultural/discursive (e.g. race, gender, class) hierarchies, although it is clear that Deleuze may reject this label (postcolonialism). On the other hand, departing from Said, Bhabha and Deleuze explore the constructive aspect of minor/minoritarian literature that may serve as a counter-discourse (resistance literature) against the majoritarian/colonial discourse.

This paper aims to survey from a postcolonial perspective the construction of subject (ivity) in literary narratives through an analogical study of some related theories of Homi Bhabha and Deleuze, both of whom show great impulse toward postcolonialism, although it is clear that both of them may reject this label (postcolonialism).

\section{Resistance Literature-A Poetics of Minor/Counter Narrative}

Nowadays, many ethnic minorities have tried to reclaim their dignities, national identities and rights through writing. As a result, writing has become a powerful and useful tool for the reconstruction of national/cultural identity. Deleuze and Guattari have declared in their collaborated work Kafka: Toward a Minor Literature (1975) that this is "the impasse" that a minority faces (p. 16). Besides, they also emphasize that the minority have to deconstruct and reconstruct their minor literature within a major language (p. 16). So, this is a very common phenomenon for the colonized who have been using the colonizer's language (e.g., people of the British and French colonies). More importantly, a minor literature is an "impossible literature," for in it "language is affected with a high coefficient of deterritorialization" (p. 16). This is the impasse that a minority has to overcome, just like the Jews of Prague, who have to "turn their literature into something impossible- "the impossibility of not writing, the impossibility of writing in German, the impossibility of writing otherwise" (p. 16).

Many postcolonial theorists, including Bhabha and Deleuze, prompt people "to rethink the limitations of the social sense of a "collective community," for they argue that "cultural and political identity are constructed through a process of alterity or otherness" (Woods, 1999, p. 44). Bhabha advocates strongly a counter-narrative that is achieved through establishing the liminality of the nation-space, giving rise to a "difference" that is "turned from the boundary outside to its finitude "within"” (Woods, 1999, p. 150). To reach this objective of national liminality in a postcolonial condition, the marginalized subjects have to reclaim their national/cultural identity through a resistance writing peculiar to the "margins and minorities." In outlining the "the incommensurable experiences of struggle and survival in the construction of a national space," Bhabha resorts to Fanon's proposition in "On National Culture" by celebrating his ideas about "warning against the intellectual appropriation of the culture of the people (whatever they may be) within a representationalist discourse that may be fixed and reified in the annals of History" (Woods, 1999, p. 152). This is a minor/counter-narrative, a supplementary strategy aiming to subvert/deconstruct the majoritarian/master discourse through rewriting or renegotiating (not negating) the dominant social codes in national histories:

The minority does not simply confront the pedagogical, or powerful master-discourse with a contradictory or negating referent. It does not turn contradiction into a dialectical process. It interrogates its object by initially withholding its objective. Insinuating itself into the terms of reference of the dominant discourse, the supplementary antagonizes the implicit power to generalize, to produce the sociological solidity. . . . The power of supplementarity is not the negation of the preconstituted social contradictions of the past or present; its force lies . . . in the renegotiation of those times, terms, and traditions through which we turn our uncertain, passing contemporaneity into the signs of history [my emphasis]. (Woods, 1999, p. 155)

Echoing Bhabha's postcolonial counter discursive strategy (aesthetics), Deleuze and Guattari establish a minor science that is "a postmodernism of resistance (emphasis added)" (Bogue, 2003, p. 102), for they advocate a minor literature by which the marginalized can employ to react against the majoritarian regime/social codes. Deleuze and Guattari argue that if the minoritarian are to subvert the majoritarian they have to deterritorialize the dominant coding imposed on them and thus open up some lines of flight, because

Resistance [emphasis added] must proceed through a becoming-other, a passage between the preestablished categories of male/female, white/non-white, adult/child, human/nonhuman, that passage constituting a "becoming-woman," "becoming-black," "becoming-child," "becoming-animal" that undoes the binary oppositions of social codes and makes possible the invention of new forms of though and interaction. (Bogue, 2003, p. 102-03)

The above-mentioned is a proposition for practicing the war machine against the State, a call for nomadic warriors against the State. For Deleuze and Guattari, to write is to become. Becomings are always becoming-revolutionary, to create a literature by using a minor language inside our own language. Deleuze and Guattari highly celebrate the minor literature which is written in a minor language resulting from "a minor use of our own language": 
Multilingualism is not merely the property of several systems each of which would be homogeneous in itself: it is primarily the line of flight or of variation which affects each system by stopping it from being homogeneous. . . speaking in one's own language like a foreigner. Proust says: "Great literature is written in a sort of foreign language. To each sentence we attach a meaning, or at any rate a mental image, which is often a mistranslation. But in great literature all our mistranslations result in beauty. (Dialogues p. 4-5).

The minor literature have subversive powers because the writer warriors gain new forces or new weapons in their becoming-other, namely, becoming minoritarian.

To be more specific, the rhetorical strategy that Deleuze and Guattari advocate is a (micro)politics of minor literature (not minority literature), which does not come from a minor language but rather a "deterritorialized" version in which a minority constructs within a major language, just like Prague German, the "paper language" employed by Kafka. As Bogue puts it, Deleuze and Guattari admire experimental artists who can create "not mere formal innovations in words, images, and sounds, but modes of action that engage immanent relations of power, destabilize them, and open up possibilities for their transformation" (Bogue, 2003, p. 102). Furthermore, the deterritorialized language uproots the old dichotomies such as East/West, Self/Other and Center/Margin.

In addition, Deleuze claims that literature also has a political function which is collective, for literature (minor writing) itself essentially expresses acts of "collective assemblages of enunciation," if the writer is marginalized or "completely outside his or her fragile community" (Kafka, p. 17-18). For Deleuze argues that the ultimate political task of writing "consists in 'inventing' a people who do not yet exist. ... The collective emerges, in this way, from the writer's creation of pre-individual singularities" (Buchanan and Marks, 2000, p. 4). Deleuze also emphasizes that literature as a collective assemblage of enunciation aims to "set free, in the delirium, this creation of a health or this invention of a people, that is, a possibility of life. To write for this people who are missing . .."; moreover, the "collective," in Deleuzian terms, is a form of "delirium" (Essays Critical and Clinical, p. 4). To illustrate, I'd like to cite the example of some minoritarian writers who are educated in some colonies of some western imperial countries like U.K and France. Nowadays, around the world we can read a lot of literary works written in English that are published by some writers under the British colonial rule. Their writing, though not intended to speak for any specific people, very frequently turn out to be a powerful weapon against the colonizer, because the minor literature helps consolidate the national or cultural identity and dignity of the colonized. In the United States, many ethnic minorities, especially the Chinese, Hispanic, and African descendants, are eagerly employing English to depict their culture-specific traditions and experiences, both the ones from their motherlands and those hybridized ones composed by their ethnic and American culture. Moreover, many of them are "deterritorializing" English in constructing their own language for writing in a sense of blending their ethnic grammar, syntax or expressions into the English language, for example, Chinglish and Black English. As a result, the contemporary American literature has marked a trend toward multiculturalism that encompass "hybrizdized" issues of gender, race and class.

Above all, both Bhabha and Deleuze (andGuattari) highly value the subverting potential of counter-narratives of the minority (minor writing/literature), for literary counter-tradition, as a hybrid offspring of the majoritarian and minoritarian cultures, "no longer designates specific literatures but the revolutionary conditions for every literature within the heart of what is called great (or established) literature (Deleuze and Guattari, 1986, p. 18); furthermore, for Bhabha, those counter-narratives "disturb those ideological manoeuvres through which 'imagined communities' are given essentialist identities" (Deleuze and Guattari, 1986, p. 149).

\section{The Gay/Minor Science: Nihilism in Bhabha and Deleuze's Postcolonial Stance}

Regarding the formation of the postcolonial subject of the nation-space, Bhabha is strongly opposed to any form of essentialist model of postcolonial identity, for he construes postcolonial identity in the "in-between space"-a cultural liminality - which emerges from the interaction or even contestation of diverse cultures or traditions, like the colonial power and the colonized culture:

The liminal figure of the nation-space would ensure that no political ideologies could claim transcendent or metaphysical authority for themselves. This is because the subject of cultural discourse-the agency of a people-is split in the discursive ambivalence [my emphasis] that emerges in the contestation of narrative authority between the pedagogical and the performative. This disjunctive temporality of the nation would provide the appropriate time-frame for representing those residual and emergent meanings and practices that Williams [Raymond Williams] locates in the margins of the contemporary experience of society. ( $p .148$ )

This cultural liminality, resulting from double-writing or dissemination, is characteristic of counter-narratives of the marginalized nation that "continually evoke and erase its totalizing boundaries - both actual and conceptual — disturb those ideological manoeuvres though which 'imagined communities' given essentialist identities" (Bhabha, 1994, p. 150). 
Likewise, Deleuze's approach to literature can be generated by his interest in the 'enigmatic 'in-between' spaces which condition the conventional components of literary texts - characters, events, dialogues and so on — but which are frequently elided" (Buchanan and Marks, 2000, p. 7). Buchanan and Marks argue that Deleuze's interest in the "in-betweeness" is generated by his "concern for the new"; namely, a fascination with the "untimely" aspect of great literature (Buchanan and Marks, 2000, p. 7). Besides, according to Deleuze, the in-betweeness is the impulse of becoming - well visualized in the Anomalous - which is neither healthy nor ill. To vividly illustrate the Anomalous, Deleuze and Guattari employ a famous persona-Moby Dick-from Melville's minor narrative:

Of having chosen Moby Dick, the white whale, instead of obeying the law of the group of fishermen, according to which all whales are fit to hunt. In that lies Ahab's demonic element, his treason, his relationship with Leviathan-this choice of object which engages him in a whale-becoming himself. . . We must define a special function, which is identical neither with health nor illness: the function of the Anomalous. The Anomalous is always at the frontier, on the border of a band or a multiplicity; it is part of the latter, but is already making it pass into another multiplicity, it makes it become, it traces a line-between [my emphasis]. (Dialogues, p. 42)

In other words, it is Deleuze's untimely "philosophical counter-tradition that gives rise to, or informs, his literary counter tradition, namely minor writing." (Note 1). The Deleuzian "untimely" minor writing is great literature, for it employs a "deterritorialized" language and deterritorializes the majoritarian modes of representation by searching for new weapons in outlining the heterogeneity and contingency of human reality - by forming lines of flight and thus creating/discovering new aesthetic worlds:

The line of flight is a deterritorialization. The French do not understand this very well. . . But to flee is not to renounce action: nothing is more active than a flight. It is the opposite of the imaginary. It is also to put to flight-not necessarily others, but to put something to flight, to put a system to flight as one burst a tube. . . One only discovers worlds though a long, broken flight. Anglo-American literature constantly sows these ruptures, these characters who create their line of flight. (Dialogues, p. 36)

To deterritorialize is also to become. According to Deleuze, to write is to become (Dialogues, p. 43), a nomadic act to produce a minor writing that creates a missing people - a collective community - in delirium.

Coinciding with Deleuze and Guattari's deterritorializing/becoming poetics, Bhabha also aims to deconstruct those binary oppositions when he advocates a literary/cultural aesthetics that highlights that aesthetics/culture as a strategy of survival, with its contingency, interdependence, and hybridity, is always both "transnational and translational" ( $\mathrm{p}$. 172). Besides, the deterritorialized language helps explore the increasing hybridity and liminality of cultural experience.

Despite that both Bhabha and Deleuze (and Guattari) share many ideas in common regarding deconstructing any essentialist claim of cultural/racial/discursive purity or transcendence, the former is more concerned with deconstructing the imperialist subject, while the latter, subverting the subject of humanism. Very often in their collaborated works, Deleuze and Guattari highly celebrate "the Superiority of Anglo-American Literature" whereas devaluing the French literature, for "the French are too human" (Dialogues, p. 37). Their common ground happens to be the correspondence between postcolonialism and postmodernism.

\section{Conclusion}

Consequently, regardless of some details of differences in their discursive stance on "collective," Bhabha and Deleuze create a literary counter-tradition/narrative (minor writing) that makes any claims for the hierarchical "purity" of an original culture untenable. In conclusion, Bhabha's and Deleuze/Guattari's theories happen to stress the mutual interdependence and construction of selfhood that exists between majorities (hegemonic groups) and minorities (marginalized groups), or between the colonizer and the colonized. To be more specific, this paper is aimed at examining how a deterritorialized literary aesthetics or an aesthetics of minor writing helps subvert the hegemonic discourse and establish a collective or hybridized identity/subjectivity in a dominant culture.

\section{References}

Bhabha, Homi K. (1994). The Location of Culture. London: Routledge.

Bogue, Ronald. (2003). Deleuze on Literature. London: Routledge.

Buchanan, Ian, \& John Marks. (eds). (2000). Deleuze and Literature. Edinburgh: Edinburgh UP.

Deleuze, Gilles. (1997). Essays Critical and Clinical. Trans. Daniel W. Smith and Michael. A. Greco. Minneapolis: $\mathrm{U}$ of Minnesota P.

Deleuze, Gilles, \& Claire Parnet. (1977). Dialogues. Trans. Hugh Tomlinson and Barbara Hobberjam. New York: Columbia UP. 
Deleuze, Gilles, \& Felix Guattari. (1986). Kafka: Toward a Minor Literature. Trans. Dana Polan. Minneapolis: U of Minnesota $\mathrm{P}$.

- - -. (1992). A Thousand Plateaus: Capitalism and Schizophrenia. London: Athlone.

Hutcheon, Linda. (1988). A Poetics of Postmodernism: History, Theory, Fiction. New York: Routledge. http://dx.doi.org/10.4324/9780203358856

Rossington, Michael., \& Homi, K. Bhabha. (1995). The A-Z Guide to Modern Literary and Cultural Theorists (Ed.). Stuart Sim. London: Prentice Hall.

Woods, Tim. (1999). Beginning Postmodernism. Manchester: MaNcherster UP.

Note 1.

See Introduction, Deleuze and Literature, Buchanan and Marks refer to Kenneth Surin's association of Deleuze and Derrida in their objection to structuralism - deconstruction in "A Question of an Axiomatic of Desires: The Deleuzian Imagination of Geoliterature." 